\title{
FACTORS THAT AFFECT USERS' SATISFACTION OR TRANSJAKARTA BUS CORRIDOR 10 CONSUMERS IN JAKARTA
}

\author{
Sonya Sidjabat ${ }^{1}$ \\ 1. STMT Trisakti \\ Corresponding author: sidjabatsonya@gmail.com
}

\begin{abstract}
TransJakarta is a transportation service in Jakarta that has been operating since January $15^{\text {th }} 2004$ with the hope of giving faster, comfortable, but also affordable service for the citizens of Jakarta. Researchers used SEM (Structural Equation Modeling) with the SmartPLS software, hence the affection of Service Quality and Customer Loyalty to Customer Satsifaction and on the other hand, the affection of Customer Loyalty to Service Quality can answer the three hypotheses.
\end{abstract}

Keywords: TransJakarta transportation service, SEM ((Structural Equation Modeling), Service Quality, Customer Loyalty, Customer Satisfaction

\section{Introduction}

One of the services sector has a vital role in supporting the daily activities are the transportation services sector. Transportation is an important developmental tool for life. The importance of transportation is reflected in the increasing need for transportation services for the mobility of people and goods as a result of increased population growth and residential development in big cities.

Aspects that support the occurrence of the acceleration of the changes include: 1) Businesses increasingly global nature 2) Changes in customer tastes, good taste of regular customers and business customers 3) Arena competition is increasingly widespread both domestically and internationally 4) The technology is increasingly leads on changing business challenges that arise usually includes aspects of customers, competitors, and change (Schoemaker, 2014).

Consumers are the only one who can judge whether or not the quality of service. Consumers are always looking for the most highly regarded value of some products (Kotler, 2009). They form expectations about the value to be obtained (value expectation). From these values can then be measured much 
satisfaction of the customers. When consumers are very satisfied with the services provided by a company will lead the consumer will be back again to hold a re-purchase (rebuying). In other words, companies that can satisfy consumers will have loyal customers. The consumer will continuously and repeatedly came to a similar place to satisfy his desire to have a product or receive a service and pay for products or services.

\section{Servqual}

(Parasuraman, Zeithaml, \& Berry, 2009) dimensions of service quality is one of the commonly used and cited components in service quality literature. The SERVQUAL scale is a 22-item scale that measures service quality along five factors (components), which forms the cornerstone on which all other research on service quality have been built (Sureshchandar, Rajendran, \& Anantharaman, 2002). (Parasuraman et al., 2009) identified ten dimensions of service quality which was subsequently collapsed into five (Talib \& Ali, 2007). They measured the above dimensions using the disconfirmation approach. According to this technique, measures of service quality can be derived quite simply by subtracting expectation scores from perception scores. These scores can be subsequently weighted to reflect the relative importance of each aspect of service quality. The outcome from a one-off study is a measure that tells the company whether its customers' expectations are exceeded or not. SERVQUAL results can be used to identify which components of a service the company is particularly good or bad at. It can also be used to monitor service quality over time; compare performance with that of competitors; compare performance between different branches within a company or measure customer satisfaction within a particular service industry.

Consumer satisfaction will be achieved if the quality of product or service provided by a company matches to the consumers want, since service quality much depends on who provides and how it is delivered. Customer satisfaction is a key success of a company; when the consumers are satisfied, they will be loyal. 
Customer loyalty is obtained through a combination of satisfaction and complaints. The higher the independent variable, the higher the customer satisfaction level will be. (Riyaldi, n.d.)

Irrespective of wide acceptance and application of the SERVQUAL scale, its disconfirmation approach has been keenly contested. (Cronin \& Taylor, 1992) are of the view that conceptualization of service quality as a gap between expectations be customers' attitude towards the service, since the concept of satisfaction is defined attitude-based conceptualization would argue for either an importance-weighted evaluation of performance -weighted evaluation of performance on specific service attributes (Cronin \& Taylor, 1992). They suggested that service quality should be measured by performances-only measures (SERVPERF). Though (Cronin \& Taylor, 1992) never altered the five dimensions of the SERVQUAL, they believe that perceptions only are better predictors of service quality. What (Cronin \& Taylor, 1992) simply meant is that the expectations component of the SERVQUAL scale should be expunged instead of using both performance and expectation components simultaneously. (Jain \& Gupta, 2004) therefore argue that the SERVQUAL scale will be able to explain greater variance in the overall service quality if measured with a singleitem scale.

\section{Service quality and customer satisfaction}

The relationship between service quality and customer satisfaction has been the focus of research. (Sureshchandar et al., 2002) found that the quality of customer service and satisfaction are strongly linked. (Dahiyat, Akroush, \& Lail, 2011) claimed that the service quality is an important antecedent of customer satisfaction. (Wang \& Shieh, 2006) found that except responsiveness, all the five dimensions of SERVQUAL explored have a significant positive effect on overall user satisfaction. Other research studies confirming the relationships between customer satisfaction and service quality dimensions depict mixed results. (Baumann, Burton, Elliott, \& Kehr, 2007) found that there is no significant 
relationship between customer satisfaction and tangible aspects of service environment. (Yuen, 2010) argued that the tangible aspects of service quality do influence customer's perceptions of service quality, which was also noted by (Warman, Firdaus, \& Rahmawati, 2015) . (Mburu, 2014) reported that responsiveness and assurance are an important drivers of customer satisfaction.

Customer satisfaction has a significant effect on customer loyalty. The relationship of service quality and customer satisfaction can not be separated from the creativity of service offered by the company. To realize a quality service that can create customer satisfaction, the company must be able to understand the level of perception and customer expectations, this is because customer satisfaction is the ratio between perception with customer expectations of service quality perceived. (Nurlita et al., 2016)

These results therefore show that customer will be satisfied with the service of a firm if they perceive such services as offering high quality. It therefore becomes necessary that organizations that want to satisfy its customers must step-up the quality of their services offerings to the customers. This is particularly important because customers who are satisfied are likely to become more attracted to the firm's offerings than those who are dissatisfied. The literatures equally show that there is no consensus on the determinants of service quality and the strengths of each component on customer satisfaction tends to differ across studies and contexts. This clearly shows why it is necessary to identify service quality attributes that impact greater on customer satisfaction in specific service settings so as to inform managers on the areas where improvements are needed. In view of this, we propose that:

$H 1$. There is strong positive relationship between service quality dimensions and customer satisfaction.

\section{Service quality, customer satisfaction and customer loyalty}

The causal link between perceived service quality and customer satisfaction, and which of this construct has a direct impact on customer loyalty 
has been debated in the literature (Cronin \& Taylor, 1992). Two basic approaches to studting this relationship have been identified in the literature.

Research on consumer satisfaction has also been studied by previous researchers (Darunanto, n.d.). Indirectly consumer satisfaction will affect loyalty as evidenced by the repurchase of products in the same company. The high company has made each company trying to meet the needs of consumers so that customer satisfaction can be achieved. Quality of service must be considered so that consumers are not disappointed and switch to other companies. Quality of service contributes to customer satisfaction.

If the services received or perceived as expected, the quality of service perceived good and satisfactory, so that will have an impact increase consumer loyalty levels. Conversely, if the service received is lower than expected, the quality of service is perceived poorly, which will have an impact on decreasing the level of customer loyalty (Saribanon Euis et al., 2016, Sekolah Tinggi Manajemen Transportasi Trisakti, 2016).

Further, the nature of relationship between satisfaction and loyalty has also been a subject of debate amongs academics. In a multisectoral study spanning four industries (i.e. banks, pest control, dry cleaning and fast food) conducted by (Cronin \& Taylor, 1992), it was found that satisfaction determines repurchase intentions. However, even though there are situations in which satisfied customer do not repeat purchase or dissatisfied customers choose to remain loyal, there is greater likelihood that satisfied customers will be loyal than otherwise. We therefore propose the following hypotheses:

$H 2$. There is strong positive relationship service quality dimensions and customer loyalty.

H3. There is strong positive relationship between customer satisfaction and customer loyalty. 
Considering the issues that emerged from literature, the proposed relationships among service quality, customer satisfaction and customer loyalty is modelled in this research as reflected in Figure 1.

\section{Method}

\section{Sample}

The sample responses were drawn from the general area of Kebon Nanas, Jakarta Timur, with specific focus on corridor 10 passengers. This is because corridor 10 has the highest concentration of service consumers in Kebon Nanas, Jakarta Timur.

\section{Measuring instrument and measures}

The major research instrument used in collecting the data for this study is the questionnaire. This was because in a review of 30 different service quality studies that the quantitative method (survey questionnaire) was the main approach for data collection. Consequently, to test the proposed research model, three variables (service quality, customer satisfaction and customer loyalty) were operationalized in line with evidences emanating from literature.

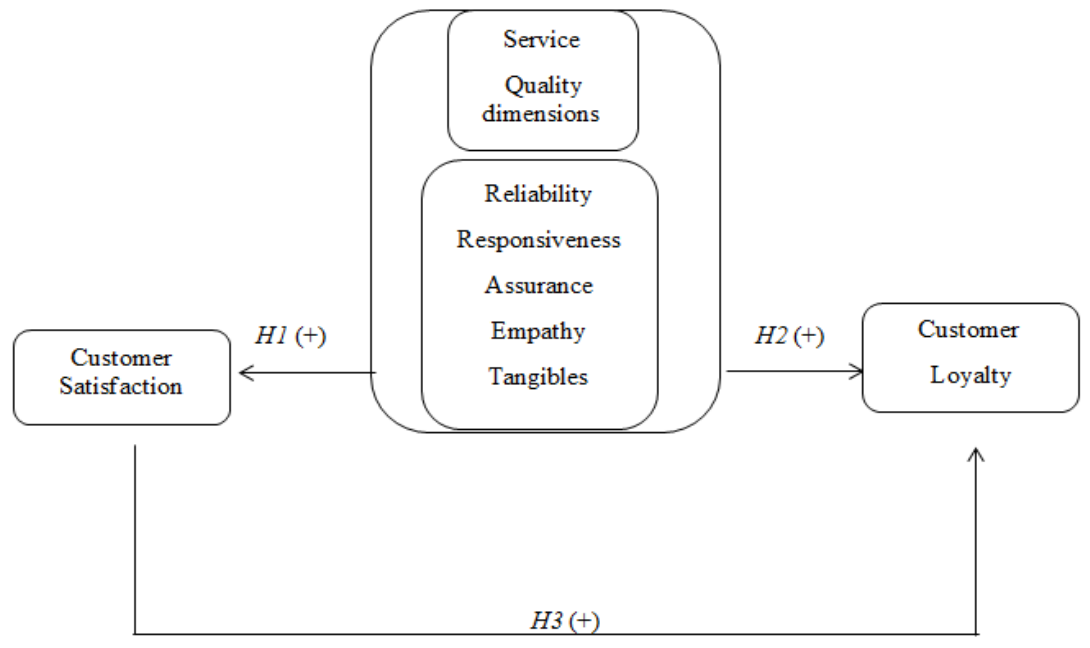

Figure 1. Research framework

Resources: Ernest Emeka Izogo and Ike-Elechi Ogba, 2015, International Journal of Quality \& Reliability Management Vol. 32 No. 3, 2015 pp. 250-269. Emerald Insight (www.emeraldinsight.com/0265-671X.htm) 
The questionnaire (scale-items) was presented in a five-point Likert rating scale with $5=$ "very strongly agree" and $1=$ "very strongly disagree" at both extremes. Likert rating scale was used because it is best suited for research designs that use self-administered surveys (Hair et al., 2006). On its own part, the five-point Likert rating scale is common because of its ability to provide participants with extended options; and literature also support the view that there is a positive relationship between the number of scale points and scale reliability.

In this research, the variables that are going to be scaled is Customer Satisfaction, Service Quality Dimensions and Customer Loyalty. Dimesions from Service Quality include: Reliatbility, Responsiveness, Assurance, Empathy and Tangibles. Indicators used in determining these variables are mentioned as follow:

Table 1. The Operational Table of Research Variables

\begin{tabular}{|c|c|c|c|c|}
\hline Variable & Indicator & Code & Scala & Sources \\
\hline \multirow[t]{2}{*}{ Reliability } & $\begin{array}{l}\text { Trans Jakarta } \\
\text { serves passengers } \\
\text { according to the } \\
\text { time promised }\end{array}$ & R1 & Likert & $\begin{array}{l}\text { Riding, et.al } \\
(2002)\end{array}$ \\
\hline & $\begin{array}{l}\text { Trans Jakarta is } \\
\text { reliable in terms of } \\
\text { serving passengers }\end{array}$ & R2 & Likert & $\begin{array}{l}\text { Riding, et.al } \\
(2002)\end{array}$ \\
\hline \multirow[t]{2}{*}{ Responsiveness } & $\begin{array}{l}\text { Workers give an } \\
\text { accurate } \\
\text { information } \\
\text { regarding the bus }\end{array}$ & RES1 & Likert & Krauss (1998) \\
\hline & $\begin{array}{l}\text { Workers inform } \\
\text { payment methods } \\
\text { that passengers } \\
\text { ought to do in order } \\
\text { to enter the waiting } \\
\text { room }\end{array}$ & RES2 & Likert & Krauss (1998) \\
\hline \multirow[t]{2}{*}{ Empathy } & $\begin{array}{l}\text { Workers in Trans } \\
\text { Jakarta bus station } \\
\text { have the effort to } \\
\text { understand } \\
\text { passengers' needs }\end{array}$ & EM1 & Likert & $\begin{array}{l}\text { Riding, et.al } \\
(2002)\end{array}$ \\
\hline & $\begin{array}{l}\text { Workers pay } \\
\text { attention to the } \\
\text { passengers }\end{array}$ & EM2 & Likert & $\begin{array}{l}\text { Riding, et.al } \\
(2002)\end{array}$ \\
\hline
\end{tabular}


Table 1, Cont. The Operational Table of Research Variables

\begin{tabular}{|l|l|l|l|l|}
\hline & $\begin{array}{l}\text { Workers look out } \\
\text { for passengers' } \\
\text { comfort when } \\
\text { entering the bus }\end{array}$ & $\begin{array}{l}\text { Riding, et.al } \\
(2002) \\
\text { norkers behave } \\
\text { nicely EM4 }\end{array}$ & Likert & $\begin{array}{l}\text { Riding, et.al } \\
(2002)\end{array}$ \\
\hline $\begin{array}{l}\text { Workers respond to } \\
\text { every questions } \\
\text { asked by passengers }\end{array}$ & EM5 & Likert & $\begin{array}{l}\text { Riding, et.al } \\
(2002)\end{array}$ \\
\hline Tangibles & $\begin{array}{l}\text { Trans Jakarta has } \\
\text { spacious bus station }\end{array}$ & $\begin{array}{l}\text { T1 } \\
\text { stans Jakarta bus has secure } \\
\text { environment }\end{array}$ & T2 et.al \\
\hline
\end{tabular}

From the calculation above, it can be seen that the $r$ (coeficient) or $r$ minimum is 0,361 . If the value attained in the validity test for more tan 30 respondents are fewer than the mínimum limit, then the statement included in the questionaire is not valid, and viceversa.

If $\mathrm{t}=1,96$ and $\mathrm{n}=200$, then $\mathrm{r}=0,11$ is attained.

From the calculation above, it is shown that $r$ or $r$ minimum is 0,11 . If the value attained from the validity test for 120 respondents is fewer than the minimum limit, then the statements included in the questionaire is not valide, and viceversa.

Analysis process using SEM method is divided into two, estimation process with each measurement model and estimation process simultaneously for Strcuctural Equation Modeling. This model is used to test if the theory suggested is suitable for the empirical model. This method's ability merge mostly in picturing correlations in within the variables, direct or indirect, which is not observed with calculating error variable, happened due to collecting datas using questionaire. If these things are let to happen, it will create bious to the interpretation.

SEM Model also allow a researcher to answer regressive ore ven dimensional (scale dimension base don concept) research questions. When a 
researcher face questions regarding dimension indentification of a concept or construct (common in factor analysis) and at the same time researcher want to also measure effect or correlatin degree between factors that have been

Validity and reliability tests are done with two steps, first step or pretest use data more than 30 respondents and second step is to use data more than 120 respondents. For both steps, results obtained are as follow:

Reliability test for 30 respondents is done manually and using no internet connection. It is hoped that from this test, feedback is gained fast when the respondent misunderstood the questions. So when test is done for all data, result will show a near statistics from the actual condition.

Table.2 Table of Validity Results for 30 Respondent

\begin{tabular}{|l|l|l|}
\hline \multicolumn{1}{|c|}{ Variable } & \multicolumn{1}{|c|}{ Inter-Item Correlation } & \multicolumn{1}{c|}{ Test Results } \\
\hline REL1 & 0,548 & Valid \\
\hline REL2 & 0,548 & Valid \\
\hline RES1 & 0,116 & Valid \\
\hline RES2 & 0,116 & Valid \\
\hline C1 & NA (Not Available) & NA (Not Available) \\
\hline EM1 & 0,661 & Valid \\
\hline EM2 & 0,615 & Valid \\
\hline EM3 & 0,471 & Valid \\
\hline EM5 & 0,562 & Valid \\
\hline EM6 & 0,570 & Valid \\
\hline T1 & 0,472 & Valid \\
\hline T2 & 0,472 & Valid \\
\hline LS1 & 0,7849 & Valid \\
\hline LS2 & 0,8550 & Valid \\
\hline LS3 & 0,8367 & Valid \\
\hline LS4 & 0,8367 & Valid \\
\hline LS6 & 0,9595 & Valid \\
\hline LS7 & 0,8867 & Valid \\
\hline
\end{tabular}

Sources: Result of observe, data used by SPSS v.23

From the result obtained from pre-test, it can be seen that there are variables gaining the value of $\mathrm{r}$ below $\mathrm{r}$ table $(0,361)$. By this being said, the validity test for 30 respondents is valid. To measure realibility, value of Croncbach's Alpha is used. The results are as follow: 
Table 3. Table of Reabilities Results for 30 Respondens

\begin{tabular}{|l|l|l|l|}
\hline \multicolumn{1}{|c|}{ Test } & Total Questioners & $\begin{array}{c}\text { Coefficient } \\
\text { Cronbach's Alpha }\end{array}$ & \multicolumn{1}{|c|}{ Results } \\
\hline $\begin{array}{l}\text { Customer } \\
\text { Satisfaction/LS }\end{array}$ & 6 & 0,789 & Reliable \\
\hline Empathy & 5 & 0,791 & Reliable \\
\hline Reliability & 2 & 0,703 & Reliable \\
\hline Responsiveness & 2 & 0,199 & Reliable \\
\hline Tangibility & 2 & 0,639 & Reliable \\
\hline
\end{tabular}

Sources: Result of observe, data used by SPSS v.23

Result of the reliatbility above shows that all coeficient of Croncbach's Alpha obtained gained a value above 0,6 . It is concluded from the test that all of the respondents' anwer of the questions used in this research is consistent and reliable.

\section{Analysis}

\section{Response rate and demographic outcomes}

Out of the 120 questionnaires distributed, a total of 120 were returned. This produced a response rate of female repondents had the highest frequency level at 58.3 per cent while the male respondents' frequency level was 41.7 per cent. It shows more women are using Transjakarta bus to go to work because of the corridor 10 with the aim of Tanjung Priok-Cililitan a lot these past offices and campuses. So quite a lot of women who choose to take the Transjakarta bus than men. As for the characteristics of the location, 50.8 per cent of respondents Transjakarta bus users are located in Jakarta, this means indicates that Transjakarta bus provides benefits not only the city dwellers, but also for the surrounding population. In terms of repondents' age, 39.2 per cent of the respondents were within the age brackets of over 25 , respectively, while 23 per cent were within the age bracket of $25-34$, respectively, whilst only 1.7 per cent of the respondents were under 54 years and no over. No respondents over the age of 54 years. This might be because it is difficult in Jakarta to find an over 54 who own car. 
Educational characteristics showed 43.3 per cent of respondents sit or have completed college and 63.3 per cent of employees, followed by 32.5 per cent of the 120 respondents with elementary education, junior high school. This means that Transjakarta bus users that most of the employees amounted to 63.3 per cent.

50.8 per cent of Transjakarta bus users residing in Jakarta. Transjakarta bus users 43.3 percent are Bachelor.

Respondents 38.3 per cent who used Transjakarta bus 4 to 5 times. Respondents 61.7 per cent used Transjakart for going and back from office.

In modifying the model into a second-order model, the researchers separated the dimensions of Service Quality namely: Reliability, Responsiveness, Assurance, Empathy and Tangibles.

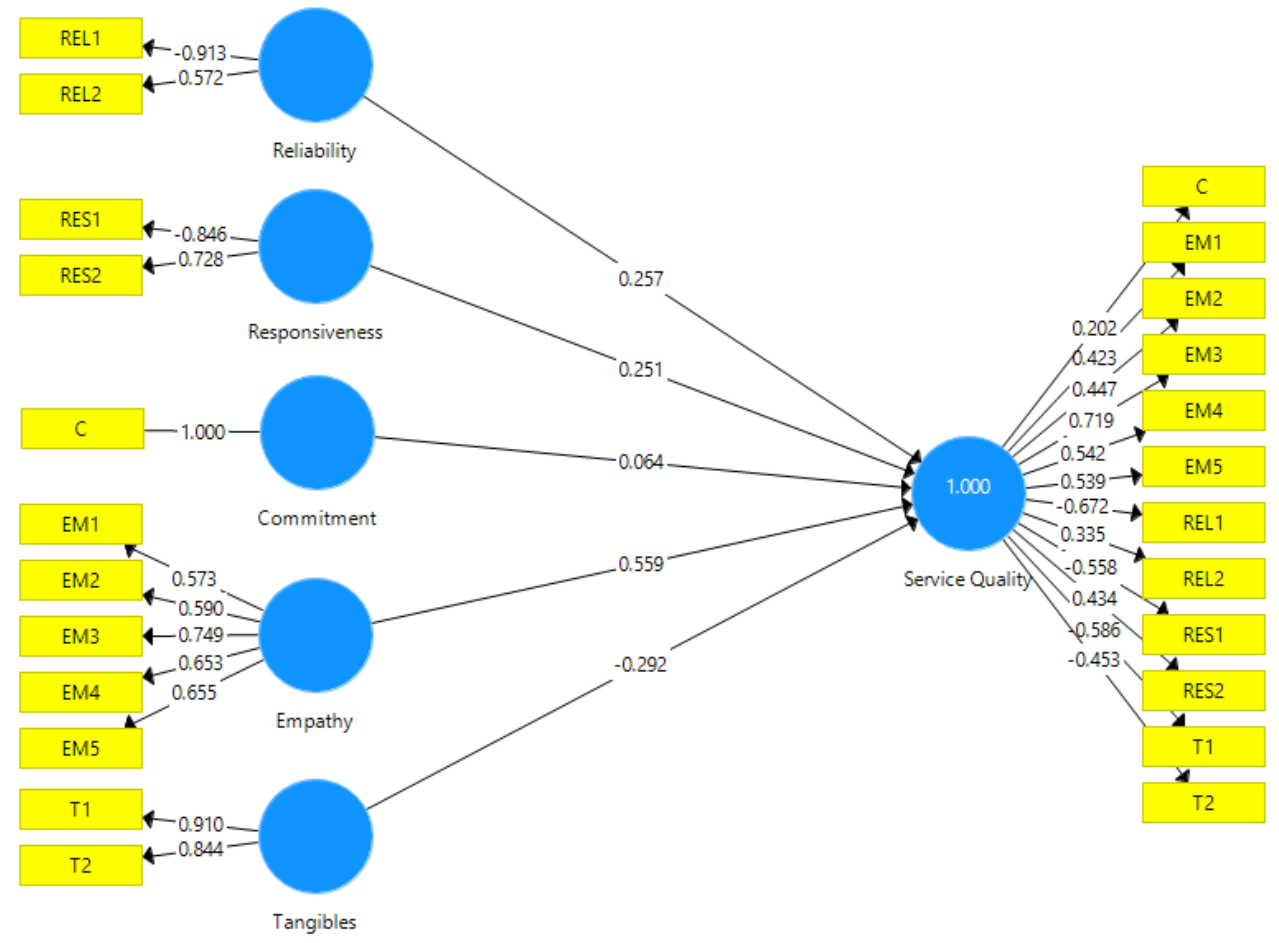

Figure 1. Results of Calculation Second Order ${ }^{1}$

\footnotetext{
${ }^{1}$ In section 3, there are several variables that are not valid as EM4, LS5. For a sample of 120 indicators used EM4 is an indicator EM5. Likewise EM5 indicators derived from EM 6 out of 30 respondents. As for the sample of 120 indicators used are indicators LS5 LS6 of 30 respondents. Likewise indicator used is LS5 LS6. Likewise indicator derived from the LS7 LS 6 of 30 respondents.
} 
Modification of variable reliability aims to be a model more in line with the reliability of data collected. Where the construct reliability which is the dimension of the Service Quality Service Quality turned into indicator's five indicators.

After calculation of the results of questionnaires conducted on 120 respondents, then the relations between variables and indicators in this study are described as follows:

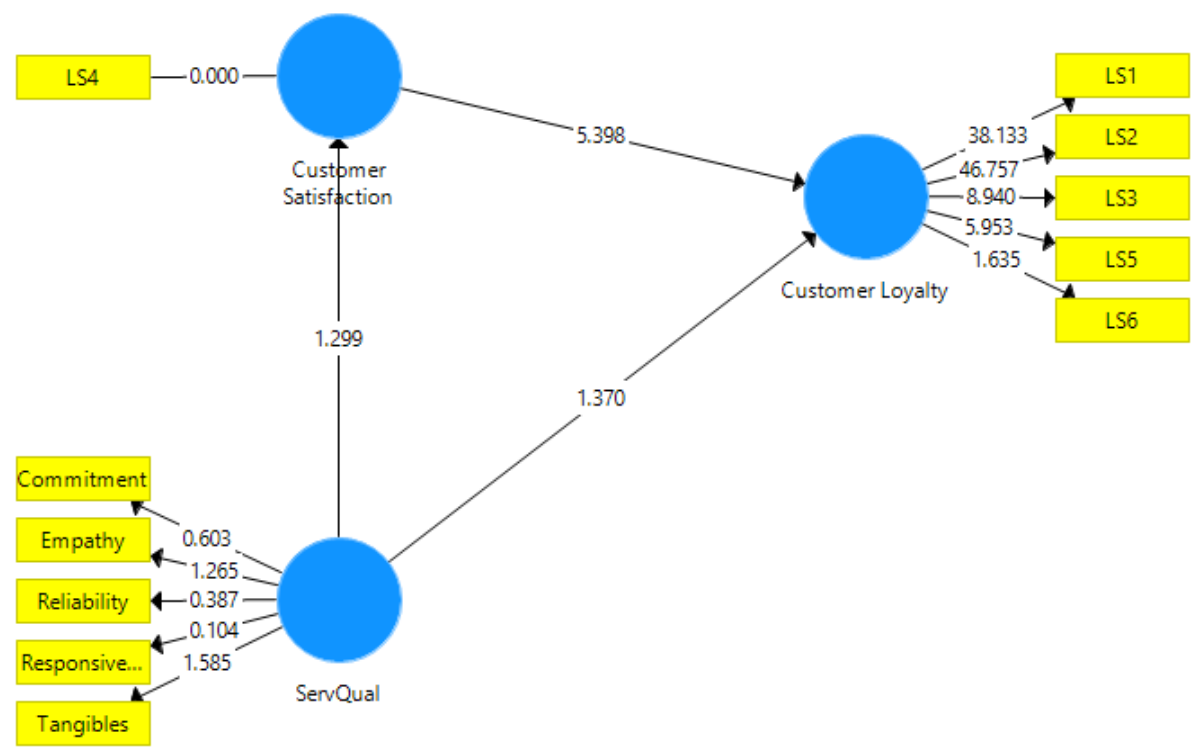

Figure 2. Relations between variables and indicators results

$\mathrm{H} 1$ predicts the existence of a strong positive relationship between service quality and customer satisfaction. The result of the calculation, $t=1.299$. The value is lower than the table $\mathrm{t}=1.64$ for $\alpha=5 \%$. The results showed that $\mathrm{H} 1$ is not proven, that means there is no significant relationship between Servqual and Customer Satisfaction.

$\mathrm{H} 2$ predicts a positive relationship between service quality and customer loyalty. The calculation result obtained $t=1,370$. The lower value of the table $t$ $=1.64$ for $\alpha=5 \%$. The results showed that the $\mathrm{H} 2$ has not been proven, which 
means there is no significant relationship between Servqual and customer loyalty.

$\mathrm{H} 3$ predicts a strong positive relationship between customer satisfaction and customer loyalty. The result of the calculation, $t=5.398$. The value is higher than the table $t=1.64$ for $\alpha=5 \%$. The results of the study support the H3, which means there is a positive and significant relationship between Customer Satisfaction and Customer loyalty.

Table 4. of Hypothesis test with $t$-value

\begin{tabular}{|l|l|l|l|l|}
\hline Hipotesis & \multicolumn{1}{|c|}{ Path t-value } & \multicolumn{1}{|c|}{$\begin{array}{c}\text { Significan/Non } \\
\text { Significan }\end{array}$} & $\begin{array}{c}\text { Refuse/Not } \\
\text { Refuse Hipotesis }\end{array}$ \\
\hline H1 & $\begin{array}{l}\text { Service Quality } \\
\rightarrow \text { Customer Satisfaction }\end{array}$ & 1.299 & Signifikan & H1 Refuse \\
\hline H2 Quality & 1.370 & Signifikan & H2 Refuse \\
\hline H3 & $\begin{array}{l}\text { Service Customer Loyalty } \\
\text { Customer }\end{array}$ & $\begin{array}{l}\text { Satisfaction } \rightarrow \text { Customer } \\
\text { Loyalty }\end{array}$ & Signifikan & H3 Refuse \\
\hline
\end{tabular}

Table $\mathrm{t}=1.64$ untuk $\alpha=5 \%$. Source of: calculation results

This study has two indicators of reliability (REL1 and rel2). REL1 a statement Transjakarta buses serving passengers on time as promised. Rel2 a statement Transjakarta bus passengers can be relied upon to serve. REL1 indicators have factor loading value of -0.913. Rel2 indicator has a value of factor loading of 0.572 . REL1 statement should be important for passengers, but contrary to expectations.

This study has two indicator responsiveness (RES1 and RES2). RES1 a statement clerk provide accurate information to the bus schedule. RES2 a statement clerk tells how the payment should be done in order to enter the passenger bus waiting room. RES1 indicators have factor loading value of 0.846. RES2 indicator has a value of factor loading of 0.728. RES1 statement should be important for passengers, but contrary to expectations.

This study has five indicators of empathy (EM1, EM2, EM3, EM4 and EM5). EM1 a statement Transjakarta bus stop clerk in an attempt to understand the needs of passengers. EM2 a statement clerk in Transjakarta bus stop giving 
attention to passengers. EM3 a statement Transjakarta bus attendant attention to passenger comfort when going into the bus. EM4 a statement Transjakarta bus attendant always be polite. EM5 a statement Transjakarta bus attendant respond to any questions passengers. EM1 indicator has a value of factor loading of 0.573. EM2 indicator has a value of factor loading of 0.590. EM3 indicators have factor loading of 0.749. EM4 indicators have factor loading of 0.653. EM5 indicators have factor loading of 0.655. EM3 statements are statements that the loading factor greater than EM5 statement, EM4, EM1 and EM2. EM3 statement is consistent with the expectations of passenger buses Transjakarta Corridor 10 .

This study has two indicator Tangibles (T1 and T2). T1 a statement Transjakarta bus has a wide stop. T2 a statement Transjakarta bus stop safe environment. Indicators T1 has a value of factor loading of 0.910. Indicators factor loading T2 has a value of 0.844 . Statement T1 has a factor loading greater than the T2 statement. This corresponds to the expectations of Transjakarta bus passengers Corridor 10.

\section{Conclusion}

From the research results can be stated in general characteristic of the majority of samples were female $58.3 \%$ and the highest at age $<25$ years. It shows more women are using Transjakarta bus to go to work because of the corridor 10 with the aim of Tanjung Priok-Cililitan a lot these past offices and campuses. So quite a lot of women who choose to take the Transjakarta bus than men. As for the characteristics of the location, $50.8 \%$ of respondents Transjakarta bus users are located in Jakarta, this means indicates that Transjakarta bus provides benefits not only the city dwellers, but also for the surrounding population.

Seventeen statement of validity and reliability of the results are valid and reliable. It can be concluded from these test results that all of the respondents' answers to the questions used in the study was consistent and trustworthy (reliable). 


\section{Refrences}

Baumann, C., Burton, S., Elliott, G., \& Kehr, H. M. (2007). Prediction of attitude and behavioural intentions in retail banking. International Journal of Bank Marketing, 25(2), 102-116. https://doi.org/10.1108/02652320710728438

Cronin, J. J., \& Taylor, S. a. (1992). Measuring Quality : A Reexamination and. Journal of Marketing, 56(3), 55-68. https://doi.org/10.2307/1252296

Dahiyat, S. E., Akroush, M. N., \& Lail, B. N. A. (2011). An integrated model of perceived service quality and customer loyalty: an empirical examination of the mediation effects of customer satisfaction and customer trust. International Journal of Services and Operations Management, 9(4), 453. https://doi.org/10.1504/IJSOM.2011.041242

Darunanto, D. (n.d.). LAYANAN TERHADAP KEPUASAN PELANGGAN PT . DMS TOUR AND TRAVEL, 201-219.

Jain, S. K., \& Gupta, G. (2004). Measuring Service Quality: SERVQUAL vs. SERVPERF Scales. Vikalpa: The Journal for Decision Makers, 29(October), 25-37. https://doi.org/10.1177/0256090920040203

Kotler, P. and K. K. L. (2009). Manajemen Pemasaran Jilid 2 (13th ed.). Jakarta: Erlangga.

Mburu, P. N. (2014). Demographic Statistics, Customer Satisfaction and Retention: The Kenyan Banking Industry. Journal of Business and Economics, 5(11), 2105-2118. https://doi.org/10.15341/jbe(21557950)/11.05.2014/015

Nurlita, L., Sekolah, S., Manajemen, T., Trisakti, T., Made, I., Sekolah, A., ... Trisakti, M. T. (2016). Loyalitas Pelanggan Pada Perusahaan Freight Forwarding Customer Loyalty of Freight Forwarding Company, 3(3), 299308.

Parasuraman, A., Zeithaml, V. A., \& Berry, L. L. (2009). Model Service Its Quality and Implications for Future, 49(4), 41-50.

Riyaldi, M. S. (n.d.). The Customer Loyalty of Patas Purwakarta Train Service Users, 3(1), 1-18.

Saribanon Euis et al., 2016, Sekolah Tinggi Manajemen Transportasi Trisakti, E. (2016). The Satisfaction of Transportation'S Customers To Enchance Loyalty. Jurnal Manajemen Transportasi \& Logistik, 3(3), 317-326.

Schoemaker, P. (2014). How to Link Strategic Vision to Core Capabilities, (January 1992).

Sureshchandar, G. S., Rajendran, C., \& Anantharaman, R. N. (2002). Determinants of customer-perceived service quality: a confirmatory factor analysis approach. Journal of Services Marketing, 16(1), 9-34. https://doi.org/10.1108/08876040210419398

Talib, D., \& Ali, K. A. M. (2007). An empirical study on the effects of service quality towards organizational performance in Malaysian local authorities. Journal of Global Business Management, 3(1), 1-10.

Wang, I.-M., \& Shieh, C.-J. (2006). The relationship between service quality and 
customer satisfaction: the example of CJCU library. Journal of Information \& Optimization Sciences, 27(1), 193-209. https://doi.org/10.1080/02522667.2006.10699686

Warman, A., Firdaus, M. I., \& Rahmawati, A. (2015). The Perceived Image of TransJakarta Bus Rapid Transit. Jurnal Manajemen Transportasi \& Logistik, 2(1), 13-24.

Yuen, E. F. T. (2010). The effect of retail service quality and product quality on customer, 17(June), 222-240. https://doi.org/10.1057/dbm.2010.13 